\title{
Addressing Environmental Health Problems in Ogoniland through Implementation of United Nations Environment Program Recommendations: Environmental Management Strategies
}

\author{
Okhumode H. Yakubu \\ Department of Public Health Sciences, College of Health and Social Services Building, \\ New Mexico State University, Las Cruces NM 88003-8001, USA; ohyakubu@nmsu.edu; Tel.: +1-575-650-4126 \\ Academic Editor: Yu-Pin Lin \\ Received: 30 December 2016; Accepted: 26 March 2017; Published: 30 March 2017
}

\begin{abstract}
On 4 August 2011, United Nations Environment Program (UNEP) submitted an unprecedented, scientific, groundbreaking environmental assessment report (EAR) on Ogoniland to the Nigerian government. This was the outcome of a 14-month intensive evaluation of the extent of pollution. The intention was that UNEP's recommendations would be implemented to restore the devastated environment, on the one hand, and on the other, counteract the numerous environmental health issues that have for decades, plagued Ogoniland. However, five years post-EAR, and despite the seriousness of the situation, no significant resolution has occurred on the part of the government or the Shell Petroleum Development Company (SPDC) or Shell. To date, millions of Niger Delta residents particularly those living in the oil-bearing communities, continue to suffer severe consequences. Although the assessment was conducted in Ogoniland, other communities in the Niger Delta are also affected. This article explores prevailing issues in the Niger Delta, using Ogoniland (a microcosm of the Niger Delta) as an example. A multidisciplinary approach for sustainable mitigation of environmental health risks in the Niger Delta is paramount, and environmental management tools offer valuable strategies. Adopting the UNEP's recommendations for addressing environmental health problems requires implementing the environmental management/environmental management system (EM/EMS) model. However, the persistent lack of political will on the part of the Nigerian government, and the grossly nonchalant attitude by Shell remain major obstacles towards executing UNEP's recommendations.
\end{abstract}

Keywords: environmental assessment (EA); environmental assessment report (EAR); environmental health; environmental management/environmental management systems (EM/EMS) model; environmental management plan (EMP); multinational oil companies (MOCs); Niger Delta; Ogoni; Ogoniland; Shell Petroleum Development Company (SPDC); United Nations Environment Program (UNEP)

\section{Introduction}

Decades of oil exploitation, exploration, and production activities in the Niger Delta have led to severe environmental degradation that has created complex problems in the region. Environmental exploitation has been a major point of contention between the Nigerian government, multinational oil companies (MOCs) - the Shell Petroleum Development Company (SPDC) in particular-and the communities affected by oil pollution. Many years of struggle between Ogoni communities and Shell to clean up oil spills from their operations have brought practically no change-of the 27 United Nations Environment Program (UNEP) specific recommendations including change in regulatory framework, 
monitoring, operational, technical, and public health, only three have been partially implemented [1]. Of utmost importance, were the eight emergency measures requiring urgent necessary action, and for which UNEP specifically assigned priority framework for redress. They were meant to address such matters as immediate supply of drinking water especially for people of Nsisioken Ogale community, whose drinking water supply was detected to have been contaminated with benzene at levels 900 times above World Health Organization's (WHO's) recommendation [2,3]. Although a 2013-2014 study suggests that provisions for portable water were made at certain locations, supply was however epileptic and short-lived. Community members resorted to purchasing water from retailers and using rainwater. For the poor who could not afford it, they resorted to use of the polluted water, seeing they had no alternative. In fact, at some point the water tankers responsible for dispensing drinking water to Ogale and Obolo communities were observed to be empty. Some of them were perpetually parked at some other locations within Eleme [4]. Investigations revealed that some households spent about 150-200 Naira to get daily clean water supply. This constitutes a substantial strain particularly in a country where approximately 60.9 percent of the population live in "absolute poverty", and about 100 million live on less than a \$1 a day [5]. Much worse for Ogoni and other affected communities, is the fact that dwellers suffer heightened deprivation of livelihood means due to severe oil pollution and associated consequences.

Both the Nigerian government and Shell have paid little attention to the cry of these people whose ecosystems, ecology, and consequently, means of livelihood have been severely impacted [4]. The relentless efforts channeled towards environmental justice by the impoverished Ogoni people culminated in the birth of the Movement for the Survival of the Ogoni People (MOSOP). MOSOP-led protests sustained the continued struggle to end the prevailing environmental degradation in the Niger Delta. The complicatedness of issues entrenched in the disagreement among people, politics, and the MOCs severely hindered the successful furtherance of MOSOP's principal goal of ending further ecological damage, and the revitalization of the polluted environment-years of negotiations and protests failed to bring about the desired solutions [6]. Finally, in July 2006, with a view to progressing from decades of standstill, the Nigeria federal government invited the UNEP to conduct an environmental assessment (EA), and propose lasting solutions to the environmental problems created by Shell, thereby ending the prolonged feud among involved parties [2,4]. Meanwhile, as part of its undying relentlessness to pursue environmental justice in the Niger Delta, and ultimately, the restoration and sustainability of the environment, on 19 January 1993, MOSOP joined the Unrepresented Nations and Peoples Organization (UNPO). The UNPO is an international democratic organization whose membership includes indigenous peoples, minorities, and isolated or uninhabited territories. Their central goal is to assure and uphold cultural and human rights, as well as to safeguard their environments by way of applying nonviolent conflict resolutions [7]. MOSOP faced horrendous challenges meted out by the military dictatorship, including various degrees of mistreatment, arrests, detention, and even killing of its members, including the execution of Ken Saro-Wiwa, MOSOP founder. Nevertheless, their unswerving efforts facilitated the eventual ejection of SPDC from Ogoni in 1993, enhancing the popularity of the entire Ogoni situation within the international community [8-12]. The Ken Saro-Wiwa-led MOSOP peaceful protest involving approximately 300,000 Ogoni people brought about this successful eviction on 4 January 1993. Ken Saro-Wiwa was executed on 10 November 1995 [12].

\section{Overview of Oil Exploration in the Nigerian State}

On 3 August 1956, oil was discovered in commercial quantities in Oloibiri, Ogbia local government area (LGA), in Bayelsa State of the Niger Delta [13]. This discovery placed Nigeria among the group of oil-producing nations, which today remains Africa's largest producer. It is estimated that Nigeria has a daily production of 2.4 million barrels, making it the 13th largest producer of oil worldwide [14]. Also, Nigeria has the second largest proven oil supplies in Africa and the 10th largest in the world. Interestingly, amidst the complexity of ethnic, environmental, political, and social problems besetting 
this highly valuable resource, it remains the principal export, and largest source of foreign earnings [15]. Petroleum has accounted for $80 \%$ of Nigerian federal government's revenue and 95\% of the country's export earnings. Apparently, oil discovery signified the dawn of Nigerian's transformation both in economic and political terms [16]. Besides being a major contributor (together with the offshore fields) to the nation's petroleum resources, the Delta buoys African's most extensive wetland-one of the largest in the world. Situated in the South geopolitical region of the country [16], the Niger Delta is considered one of the most densely populated African regions [17], also serving as habitat to certain very rare species [18]. It has the largest mangrove forests in Africa, and is the third largest in the world. It represents the most abundant part of the country in terms of petroleum resources, and diverse natural ecosystems, supportive of numerous species of terrestrial and water-living organisms [19-21].

Regrettably, this primeval natural resource has suffered incalculable ravages by oil prospecting for decades, significantly affecting host communities and their dwellers. According to research, oil spills have had long-term devastating effects on the locals, particularly those who are directly affected. Much worse is the effect on dry lands and freshwater swamps, which hold the means of livelihoods for millions in the region. In these environments, impacts were determined to be concentrated, thus exerting more chronic and catastrophic environmental and health effects. Furthermore, research suggests that the mangrove forest is notably susceptible to hydrocarbon contamination due to its soil properties. Oil is absorbed, retained, and re-liberated once the rainy season starts, thus aggravating the extent of pollution. In the event of oil spills which is usually gushed over a large area from source, arable crops including cassava (Manihot esculenta), corn (Zea mays), and vegetables; shrubs and highly economically valuable trees like oil palm (Elaeis guneensis); fish farms, as well as other valuable assets are destroyed. The overall impact potentially deprives households of as much as an annual supply of food or income. This may impose a ripple effect in that for some, the implication apart from the health impacts is some socioeconomic consequences, including pupils missing school. In some cases, it takes more than a few months and up to a few years to recover from such havoc [11].

This all boils down to the fact that oil production involves severe environmentally destructive activities, especially exploration and exploitation. They entail tree-felling, installation of drilling equipment and pipelines [21]. Among these, seismic activities and drilling constitute the most severe environment-damaging activities. The former involve deforestation and the application of explosives to generate sub-surface maps [11]. In the process, the ecology is impacted: soil structure, vegetative cover, areal fauna and flora populations are critically altered. Additionally, the soil is exposed and consequently its vulnerability to erosion is heightened. Drilling on the other hand, involves "bush clearing" for creating access roads and waste pits [11]. In situations where exploration and exploitation occur in the mangrove area, dredging (removal of sand, silt and mud) is carried out using a dredging machine to provide access routes. The adverse environmental effects include hydrological changes and groundwater pollution. Worse still, oil production activities generally pollute both surface and groundwater with benzene, toulene, ethylbenezene and xylene (BTEX) as well as other toxic chemicals including toxic polyaromatic hydrocarbons (PAHs) [22]. The environmental health consequences are far reaching, particularly in most areas of the Niger Delta where residents are dependent on very shallow wells connecting aquifers [23]. Offshore oil exploration/exploitation is also in practice, and accounted for as much as 30\% of total oil production in the 1980s. To date, it is still employed and constitutes a principal source of revenue. Much as its contribution to the national oil yields is significant, and so is its environmental consequences [21].

Unquestionably, the oil industry has had very grave and consequential impacts on the Niger Delta and its people. Some specific major disasters include the killing of 180 people, which occurred as a result of the extensive 1980 Texaco spill that poisoned streams serving as drinking water sources, and those that have killed children, leading to the hospitalization of about a hundred other villagers, due to the consumption of water contaminated by oil leaks [11]. Furthermore, the ruinous and shocking effects of environmental pollution is depicted in results obtained from analysis of water samples from Luawii community in Ogoni, in 1997. Water used for drinking and other domestic purposes was 
sampled from water sources within communities where oil production had ceased for the past 4 years. Samples were then analyzed in the US. The result showed that hydrocarbon content of the samples was 18 parts per million (ppm), 360 times the tolerable limits for drinking water by the European Union (EU) standards. In addition, the samples from Ukpeleide, Ikwerre contained even higher amounts-34 ppm, 680 times the acceptable limits by the EU specification [11].

\subsection{Ogoniland}

Ogoniland has a population of close to 832,000 [2], and a population density of $1250 \mathrm{~km}^{2}$ [16]. The region administratively has four LGAs, namely: Eleme, Gokana, Khana, and Tai [2]. Covering around $100,000 \mathrm{~km}^{2}$ in Rivers State, Ogoniland is one of the prominent areas in the Niger Delta region, and has been the site of oil industry operations since the late 1950s. It has a calamitous history of pollution from oil spills, gas flares, and oil well fires.

The area is naturally endowed with an abundance of rivers, creeks, and streams. Consequently, it has predominantly traditional fishers and farmers. In the past, it was referred to as the "food basket of the Niger Delta" because it produced cash crops for neighboring Niger Delta regions as well as subsistence agriculture. This traditional practice enhanced sustainable management of the abundant natural resources [3].

\subsection{Oil Conflict}

Undoubtedly, the history of oil operations in the Niger Delta is one characterized by continued dispute among the people and the oil industry, on the one hand, and strong discord between the people and the government, on the other. This led to a morbid atmosphere of animosity, buck-passing, and distrust over the years [2]. The situation was further fueled by a military dictatorship ruling at the time. Unfortunately, in Nigeria's 57 years of existence as an independent nation it has been ruled by a democratic government for no more than 18 years. Military interference resulted in six successful coups that ended three democratically elected governments between 1966 and 1993. Military rule was characterized by fundamental human rights abuse facilitated by the suspension of federal constitution. Lamentably, Nigeria has been ruled by the military for 39 years [24].

Amidst the continued "despoliation" of Ogoni's natural resources, anthropological environmental degradation, persistent poverty due to deprivation of livelihood means, and utter disregard for culture and tribal language, the Ogonis presented the "Ogoni Bill of Rights" (OBR) to the government and people of Nigeria in 1990. The same bill was concomitantly presented as an appeal to the International community through MOSOP. OBR mainly demanded political autonomy of the Ogoni people as a recognizably separate division to partake in the dealings of its "Republic", assuring direction, and exercising restraint politically over the affairs of the Ogonis. It was also suggested that this autonomy would authorize the use of a significant portion of Ogoni economic resources for the development of Ogoniland, acceptable delegation in national institutions in terms of rights, and of utmost importance, the prerogative to preserve the ecology and environment from additional destruction. This was presented against the backdrop of the huge economic benefits (30 billion USD, at the time) that the Nigerian state has gained from Ogoniland, yet the people gained nothing, lacking basic amenities including pipe-borne water, electricity, job opportunities, federal government projects, and representation in federal government institutions. The OBR has been described not only as a novel effort containing Ken Saro-Wiwa's ingenious ideas [25,26], but also an unprecedented bill that was directed to both the Nigerian government and MOCs (Shell in particular). It is a veritable representation of the original development, since inception, of a self-determination movement [26]. It also provided the template for other minority and disenfranchised groups to crop up and pursue their own recognition, social justice, and human rights. These includes the Kaiama Declaration of the Ijaw Youth Council (IYC), and the Movement for the Emancipation of the Niger Delta (MEND) [1]. 
The ensuing years of Shell's eviction from Ogoniland in 1993 was marked with various unfruitful negotiations and protests-no proffered solution seemed to work, either to favor or meet the prospects and demands of any of the parties involved [27].

\subsection{The UNEP EA}

At the dawn of a new democratic government spearheaded by retired General Olusegun Obasanjo in 1999, efforts directed towards moving forward and ending the deadlock commenced in 2005. Therefore, the government in consultation with various stakeholders invited UNEP to conduct an EA, with a view to reaching an agreement that would benefit all parties. This supposedly, would ultimately foster the resumption of business operations by Shell in Ogoniland. The UNEP EA entailed a 14-month exhaustive evaluation of diverse parameters, including aquatic life, air pollution, contaminated land, groundwater, surface water, sediments, soil, public health, industry practices, and institutional problems [2,4]. The outcome of this was a cutting-edge report that has been described as "... epitomizing the best available insight of the Ogoni situation, as well as the implication for impacted people ..." " [2]. Also considered one of the most intricate on-the ground evaluations ever carried out by UNEP, their EAR provides first time, systematic, and scientific based evidence available to the public on the exact nature, magnitude, and impacts of oil pollution in Ogoniland. Furthermore, the report contains recommendations that would bring about restoration of the devastated ecology and ecosystems, including urgent measures requiring immediate action by both Shell and the federal government of Nigeria. Such measures include among other things providing safe drinking water to communities with contaminated water.

\section{Oil Production-Related Environmental Health Problems}

\subsection{Air Quality}

The environmental pollutants discharged from the continued flaring of gas in communities of the Niger Delta, severely impacts air quality. This has detrimental consequences on the people. Sadly enough, even though legislation regulating gas flaring has been passed with the aim of completely phasing it out, including the 1984 complete prohibition [28] target, the operation continues in other parts of Niger Delta, having stopped in Ogoni. Although, there seem to be a dearth of studies aimed at evaluating the health impact of poor ambient air quality on humans in the Niger Delta [29], it may be fair to say that there is still a reasonable number of published articles disclosing substantial (adequately sufficient to motivate necessary action) information related to the fact.

Natural gas is currently mostly disposed of either by flaring or venting. Gas flaring refers to the process of burning the gas on reaching the ground surface during exploration and exploitation processes. Venting, on the other hand, involves discharging the gas into the air without burning [30]. In addition, Emam [30] describes flaring as the controlled combustion of unprocessable (due to technical or economic reasons) natural gas that may otherwise be sold or used. Both practices involve atmospheric discharge of hazardous substances and are therefore environmentally unfriendly, constituting major source of air pollution that have had very severe environmental and public health consequences in the Niger Delta. Research indicates that over the past decades, over $75 \%$ of associated gas produced has been flared, representing an equivalent of 45 million tons of carbon dioxide per day. According to Agbola et al. [31], an estimated 45.8 billion kilowatts of heat are emitted from flaring, an average of 1.8 million cubic feet of gas per day. Similarly, the Fridtjof Nansen Institute [32] and Nriagu [33] posit that gas flaring in the Niger Delta adds an approximate 35 million metric tons of carbon dioxide and methane, annually. The issue is further aggravated by the inefficiency of the flare systems, which leads to incomplete combustion of the gas, giving rise to the formation of various hazardous organic products such as volatile organic compounds (VOCs), polyaromatic hydrocarbons (PAHs), and a number of inorganic pollutants [34]. The result of this is a complex interaction of thermal pollution and air pollutants, which can give rise to further complex substances that are harmful to 
human and environmental health. Owing to incomplete combustion, a larger percentage of the flared gas released is methane. This has, over the decades, increased the amount of greenhouse gases (GHGs) in the atmosphere, hence increasing the global warming potential of the region. Having over 123 flaring sites, Nigeria is known to be the largest gas producer in Africa [35], and one of the highest emitters of GHGs globally, along with Russia and Iran. Although records show a $29 \%$ reduction in gas flaring in the Niger Delta between 2005 and 2010, it is nonetheless described as "still" consequential as it did not change the country's situation as one of the worst offenders in gas flaring, second only to Russia [36].

One major observable lifestyle of the Ogoni people is the fact that most of their daily activities such as farming, fishing, bathing, cooking, and most other domestic chores are outdoor-related. Hence, they are being exposed to the "too numerous to count (TNTC)" toxic chemicals, including benzene, dioxin, and benz[a]pyrne [23,37]. The quantities of these emissions far exceed both local and international standards, and have had various severe health consequences [38] such as asthma, respiratory difficulties, premature deaths, cancer, and miscarriages among pregnant women [2,38,39]. Some of the health impacts are shown in Table 1.

Table 1. Some human health effects of gas flare pollutants in the Niger Delta.

\begin{tabular}{|c|c|c|}
\hline Serial No. & Chemical Name & Human Health Effect \\
\hline 1. & $\begin{array}{l}\text { Alkanes: methane, } \\
\text { ethane, propane }\end{array}$ & $\begin{array}{l}\text { Low levels: Can result in swelling, itching and inflammation [39]. } \\
\text { High levels: May cause skin infections such as eczema and acute } \\
\text { lung swelling [40]. }\end{array}$ \\
\hline 2. & Alkenes: ethylene, propylene & May result in weakness, nausea and vomiting [39]. \\
\hline 3. & BTEX & $\begin{array}{l}\text { They are toxic and are either carcinogenic or probable } \\
\text { carcinogens }[39,40] \text {. Targets on exposure are usually the nervous } \\
\text { system and blood forming organs [40]. }\end{array}$ \\
\hline 4. & Carbon monoxide & $\begin{array}{l}\text { Low levels: Can cause permanent damage to the heart and brain [40]. } \\
\text { May harm the mental development of fetus and children [40]. } \\
\text { High levels: Can lead to miscarriage and death [40]. }\end{array}$ \\
\hline 5. & Hydrogen sulphide & $\begin{array}{l}\text { Low levels: Nausea, headaches, delirium, disturbed equilibrium, } \\
\text { tremors, convulsions, and skin and eye irritation [40]. } \\
\text { High levels: Respiratory tract and mucous membrane irritation; } \\
\text { may cause immediate or delayed pulmonary edema [40]. } \\
\text { May result in extremely rapid unconsciousness and death [40]. }\end{array}$ \\
\hline 6. & $\begin{array}{l}\text { Nitrogen dioxides } \\
\left(\mathrm{NO}, \mathrm{NO}_{2}\right)\end{array}$ & $\begin{array}{l}\text { Low levels: Cause irritation of eyes, nose, throat, and lungs. } \\
\text { Cough, shortness of breath, tiredness, and nausea may also occur. } \\
\text { Build-up of fluid in the lungs } 1 \text { or } 2 \text { day(s) after exposure is also } \\
\text { possible [40]. } \\
\text { High levels: May result in rapid burning, spasms, and swelling of the } \\
\text { upper respiratory tract and throat tissues. } \\
\text { Reduced oxygenation of body tissues, a build-up of fluid in lungs. } \\
\text { Death [40]. }\end{array}$ \\
\hline 7. & Sulphur dioxide & $\begin{array}{l}\text { Low levels: Asthmatics are very sensitive to respiratory effects [40]. } \\
\text { High levels: Burning sensation of the nose and throat, breathing } \\
\text { difficulties, and severe airway obstructions were observed in miners } \\
\text { exposed to a copper mine explosion [41]. } \\
\text { A } 100 \text { ppm in } 100 \text { parts of air has been demonstrated to be } \\
\text { immediately dangerous to human health and life [40] }\end{array}$ \\
\hline
\end{tabular}

Research suggests that the impact of exposure to these toxics including BTEX generated from flaring gas implies severe health risks, especially to those who live or work in close proximity to the flare sites within the host communities [22]. Furthermore, gas- flare air pollutants are known to exhibit some correlation with such diseases as developmental, neurological, and reproductive abnormalities, apart from cancer [23]. Previous studies indicate complaints of diverse health effects by those who live nearby flare sites; and unfortunately, most gas flaring sites in the oil-bearing communities are situated in close proximity to residences of the locals [42]. In comparison to residents of the control community 
(Ayama), with no history of gas flaring, Gobo et al. [41] established an association between residents of a study community (Igwuruta/Umuechem) having a long history of gas flaring, with frequency of such health conditions as asthma, and eye and skin irritation, as well as cough. Clinical studies have also indicated a correlation between the rapid onsets of bronchoconstriction in asthma patients and as low as 0.25-0.5 ppm sulphur dioxide levels [42-44].

\subsection{Food Quality/Supply}

Due to the prevailing widespread pollution, agricultural lands have been severely impacted causing a reduction in the quantity of harvest. In addition, because of the direct contact with plants, or indirect contact via the absorption of nutrients from contaminated soils, the quality of food is severely impacted [45]. Notable among these are the high reduction in the ascorbic acid content of vital vegetables like water leaf (Talinum triangulare), spinach (Spinach oleraceae) and garden egg (Solanum melongena), whose vitamin C contents were reduced by 36\%, 40\% and 19\% respectively [45]. Along the same line, the major staple, cassava (Esculenta spp.) planted in oil polluted soils had its crude protein content reduced by 41\% [46]. Although, according to UNEP's 2011 findings, fish contamination was not as high as expected, they discovered that they had migrated to safer and cleaner water. This is forcing fishers to travel very long distances from their localities [2]. In terms of health impacts on the locals, Gobo [41] argue that the prevalence of diarrhea in the Niger Delta is on the rise because of the consumption of fish and other animals contaminated by hydrocarbons contained in the spilled oil. Furthermore, it has been determined that bioaccumulation of benzo (o) pyrene, other hydrocarbons, and heavy metals, has occurred in toxic amounts in major high protein content sea foods, such as periwinkle (Tympanotonus fuscatus) and the Mudskipper (Periophtalus papillio), [47]. Additionally, accumulation of oil in plants' roots causes them to wilt thus substantially reducing harvests of cash and food crops [2].

\subsection{Waste Disposal/Hazardous Chemicals}

Produced water is the major waste product generated from petroleum exploration and production activities. Others include spent drilling muds, and drilling cuttings. Produced water is known to be a complex composition of numerous hazardous chemicals, including large quantities of heavy metals, inorganic, and organic substances, including naturally occurring radioactive materials (NORMs) [48-50]. According to Telleza et al. [51], the two main disposal methods for produced water are environmentally unfriendly. The array of hazardous chemicals contained in petroleum waste streams and their unwholesome disposal has resulted in untold damage to environmental media that are unyielding to known remediation technologies.

In its 2011 Assessment of Ogoniland, the UNEP project team detected the indiscriminate disposal of numerous industrial packing bags containing 1000-1500 $\mathrm{m}^{3}$ of waste, suspected to be cuttings from oil drilling operations. These were dumped at an open site where they constituted severe human and environmental health risks. Such open waste disposal in unlined pits is an indication of how compliance with environmental regulations is severely contravened by all the parties involved, including the waste generator, transporter, as well as disposal agents [2].

\subsection{Water Quality}

Oil spills end up in the environment including water, contaminating waterways, imparting a significant detriment to marine life and sources of water for domestic use. Further, discharged oil often sinks into groundwater, contaminating it. It has been established that such polluted ground water is usually difficult to remediate, and the process of remediation can take many years. Once underground, the polluted water system is transported within and between water systems that end up in wells and streams that supply the surrounding communities. These communities depend on such water resources for their only source of drinking water [6]. 
Studies indicate that acid rain is widely distributed in the Niger Delta region [52-55]. On average, a pH value of 5.06 from a range of 4.98-5.15 [56] is usually obtained. This has had a tremendous impact on the roofs of houses, as homes with corroded roofs are commonplace within the communities.

The U.S. Department of Energy (DOE), estimates that well above 4000 oil spills, resulting in the emission of millions of barrels of crude oil into various surface water sources, including creeks, streams and rivers have occurred in the Niger Delta from as far back as 1960 [57]. To date, water pollution remains one of the major environmental public health problems arising from extensive oil operations in the region. The health of a considerable number of Ogoni residents has been severely impaired due to surface and underground water contamination [2].

\subsection{Ecosystem Alterations}

Bodo Creek was characterized by low tidal energy current, making its swamps and canals exceptional breeding grounds for a vast variety of fish and shellfish. It also provides an excellent habitat for periwinkles (Tympanotonus fuscatus; Tympanotonus fuscatus varradula; Pachymelania aurita; Pachymelania fusca) [1]. The original diversity of shellfish found in the Creek included bloody cockle (Senilia senillis), oyster (Crassostrea gasar), swimming crab (Callinectis amnicola), razor clam (Tagelus adansonii), land crab (Cardisoma amatum), and mangrove purple hairy crab (Goniopsis pelli) [58-61].

Research suggests that pre- and post- oil spills show significant fall in macrobenthic $(0.5 \mathrm{~mm}-5 \mathrm{~cm}$ animals that live in or on sediments) population in Bodo Creek. In fact, as much as $81 \%$ of the initial population was lost, and two resampled sites had completely lost their faunal population [58].

\subsection{Other Problems}

\subsubsection{Policy Issues}

Records indicate the existence of well over 25 major environmental laws in the country. Prominent among them are the Oil Pipelines Act (OPA) 1956 (amended in 1965); Oil in Navigable Waters Acts (ONWA, 1968); Petroleum Acts (1969); Associated Gas Re-injection Act (AGRA, 1979); the Federal Environmental Protection Agency (FEPA) Act (1988); the National Policy on the Environment, 1989 (revised in 1999); National Environmental Protection (Effluent Limitations) Regulations (1991); Environmental Protection (Pollution Abatement in Industries Generating Wastes) Regulations (1991); Environmental Impact Assessment (EIA) Act (1992), and Department of Petroleum Resources (DPR) Environmental Guidelines and Standard for the Petroleum Industry in Nigeria (EGASPIN) (2002) [62] Unfortunately, none of these laws are fully implemented or enforced by Nigerian courts. Furthermore, there is ample evidence that since the late 1930s when businesses commenced oil prospecting in the nation, there has hardly been any account of penalties imposed on sanctionable environmental crimes arising from oil exploration and production activities [63]. According to Allen [64], there are many instances where the oil companies either adopted substandard clean-up methods or turned a blind eye to oil spills, such as the 2008 spills in Ogoni communities of Bodo and Goi, linked with the operations of SPDC. He further asserts that hosts of the environmental issues that have befallen the region have their roots in the Land Use Decree of 1978, which deprived communities the ownership rights or claims, and rendered them powerless in oil decision-making. This resulted in the oil companies having full access to communal lands with no restrictions, thereby causing devastation, and consequently increasing poverty in the region.

Surprisingly however, in January 2015 a twist to the "normal" was observed-the international Bodo vs Shell litigation was settled out of court when Shell compensated over 15,000 individuals for damages caused by the 2008-2009 spills that ravaged the Bodo Creek and ruined the fishing livelihood of the plaintiffs. The $£ 55$ million (about $\$ 86$ million) settlement was split into two parts: $£ 35$ million (about $\$ 55$ million) was shared among the plaintiffs, so that each received about 600,000 Nigerian naira (about \$3000); and the remainder, £20 million (about \$31 million) was set aside for community trust 
funds. This is so far "a first of its kind" settlement in the history of MOC payoffs made in the Niger Delta and presumably, in sub-Saharan Africa. In contrast to the Wiwa vs Shell case in New York [12], the former represents one involving an overall much larger chunk of monetary reimbursements made directly to affected individuals in numbers over 1500 times more. Equally important is the fact that Shell accepted liability, and took responsibility for the spills. However, to date, Shell has yet to effectuate its clean up promise. This historical payoff achievement may however not be attributable to "effective enforcement" of Nigerian environmental regulation, as in this particular case Shell was not brought into account by any of Nigerian enacted legislations.

\subsubsection{Socioeconomic Issues}

The majority of people lack adequate access to clean water or healthcare. According to the United Nations Development Program [2], more than 60 per cent of the people in the region depend on the natural environment for their livelihood. For many, the environmental resource base which they use for agricultural activities, fishing, and the gathering of forest products, is their principal or sole source of food. Oil spills on land seriously affect the growth and development of crops, and damage the soil quality, fertility, and ultimately, its productivity, rendering farmers in the communities unproductive. In addition, oil in water destroys fisheries, and pollutes water that people use for drinking and other domestic purposes. When gas is flared, the combustion is often incomplete, so oil droplets fall on waterways, crops, houses and people. Some homes in the communities have been rendered inhabitable, due to the prevailing unsanitary environmental conditions. People, especially young men, who have been deprived of their means of livelihoods, have resorted to pipeline vandalization, to "make up" for their losses, and to combat the lingering impoverishment that has befallen them [65]. This in a way "sustains" the vicious circle-the convoluted problem (Figure 1).

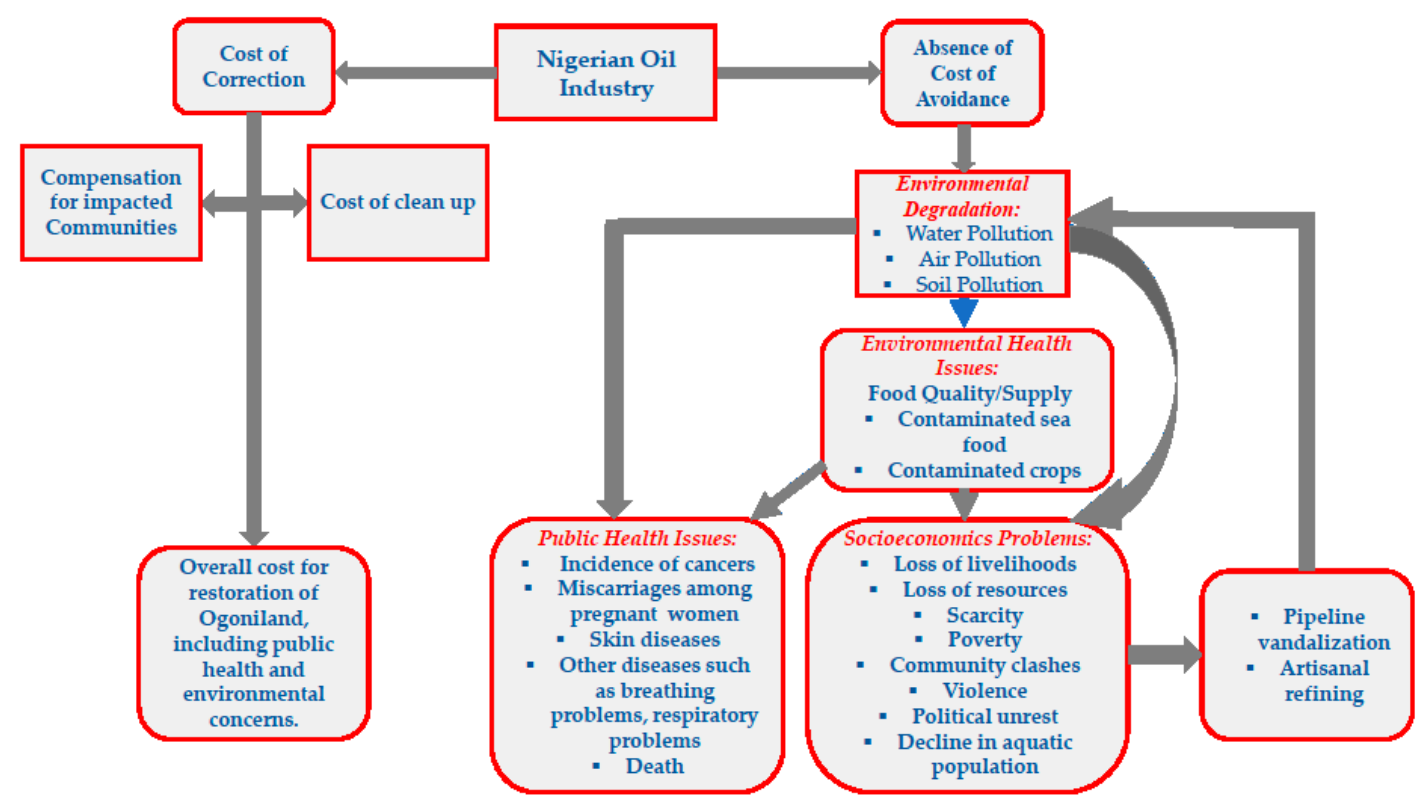

Figure 1. "Cost of Quality" conceptual framework showing the convoluted environmental, public health, and socioeconomic issues in Ogoniland.

\subsubsection{Cultural Deterioration}

Traditional use of creek water has also been completely lost. Owing to the extent of pollution, uses such as bathing, cooking, and other domestic chores, medicinal use and post-natal rituals have to a significant extent, ceased. Furthermore, some communities such as Bodo have lost use of the Creek as a waterfront and venue for community recreational activities such as for relaxation spots [1], the Kozo Beach Party and Canoe regatta, as well as the local market. Moreover, they have completely 
lost their cultural beliefs and rituals as they relate to coastal shrines and masquerades, as well as cultural singing and dancing troupes that afforded households a strong basis for social cohesion [1]. It has deprived the elderly of gift fish they used to receive from younger fishers who "paid homage" on arrival from fishing trips. Research also suggests that it has a very strong influence on social aspects of young men and women. It is nowadays common among the affected people to find men who attain marriageable age that delay getting married because they can no longer afford the expensive bride price. Also, burial ceremonies are being delayed as far as a year following the passing away of a family member, because of the unaffordable funeral expenses. Following the occurrence of a devastating spill event, there has been increased migration rates by residents as they look for greener pastures or other means of livelihood elsewhere [1].

\section{UNEP EAR}

UNEP experts, in a 14-month period, assessed over 200 sites within the Ogoni confines, evaluated approximately $122 \mathrm{~km}$ of pipeline rights of way, reviewed an estimated 5000 medical records and involved about 23,000 people at local community meetings. Furthermore, soil contamination investigations were conducted at 69 sites. Overall, more than 4000 samples of ground water and soil from numerous sites were analyzed. Although the assessment was carried out in Ogoniland, the recommendations would serve as a guide for pollution management elsewhere in the Niger Delta region. The following were highlighted in the report:

\subsection{Widespread Pollution in Ogoniland}

The findings from the unprecedented EA suggest that the environmental degradation arising from the widespread pollution is extensive. Therefore, a comprehensive environmental restoration effort is required for full rehabilitation of Ogoniland that may require as many as 25 to 30 years for completion. This necessitates an initial 1 billion US dollars set aside for the first 5 years of a 30-year clean-up project in Ogoniland alone.

\subsection{Faulty Institutional Frameworks}

The major petroleum regulatory bodies-the Department of Petroleum Resources (DPR), and the National Oil Spill Detection and Response Agency (NOSDRA) have conflicting responsibilities, and subsequently, implementation of the dictates of the Environmental Guidelines and standards for regulating the petroleum industry in Nigeria (EGASPIN) is complex. EGASPIN was issued in 1991 by DPR to enforce compliance with existing environmental regulations by the petroleum industry operators, so as to safeguard the environment from degradation by their activities. It was prepared following the Petroleum Act of 1969 [66,67].

The lack of consistency with established regulations contained in EGASPIN, as well as a lack of agreeable implementation, led to various forms of mismanagement and infractions of best practices, including premature shutting off of the remediation process before contamination has had a chance to be eliminated, and soil or water quality restored. A revised publication of EGASPIN was published in 2002. Even though EGASPIN constitutes the sole operational groundwork for environmental governance of the Nigerian oil industry, it has been found deficient. There is constitutional incoherence regarding the most vital requirements for oil spill and contaminated site management-particularly, the criteria which trigger remediation or highlights its closure (called the "intervention" and 'target' values respectively) [6]. These responsible government regulatory authorities were reported to be inadequate in terms of technical expertise, and other vital resources. For instance, NODSRA, even after 5 years following its establishment, lacked proactive capacity to productively and economically detect spills, and proffer lasting remediation processes. Further, in most oil spill site inspections, they are completely dependent on the oil companies for logistics backing $[4,6]$. 


\subsection{SPDC's Poor Environmental Management (EM) Practices and Policy Implementation}

While several MOCs operate in Ogoniland, SPDC operations have been determined to be the principal cause of the widespread pollution. UNEP reported that 10 out of the 15 investigated sites which SPDC records pointed out as having completed remediation, still had pollution exceeding SPDC, as well as government regulatory remediation closure values. Moreover, the report also suggests that the contamination at eight of these sites had migrated to groundwater. UNEP's report evidenced SPDC's deficient remediation processes, and described them as unfit for Ogoniland and therefore require scrutiny and reevaluation. Furthermore, "completed" remediated spill sites were inaccurately recorded. The report also highlighted the ineffectiveness of the remediation by natural attenuation (RENA), the only remedial method adopted by SPDC, and therefore its inadequacy to either accomplish environmental clean-up or conform to regulations as well as meeting requirements of SPDC's own established procedures.

\subsection{Nsisioken Ogale Community}

The most serious case of groundwater contamination was detected in Nisisioken Ogale, where an $8-\mathrm{cm}$ layer of refined oil was observed floating on the groundwater that serves the community wells. Additionally, members of the community were drinking water from wells contaminated with benzene, a known cancer-causing chemical, at levels over 900 times above the WHO guidelines. The EAR emphatically categorized required action on this matter as "emergency measures". The medical registry and meticulous follow-up for people of this community, as well as provision of adequate safe drinking water, were also classified as "priority measures" [2]. Furthermore, UNEP specifically emphasized prioritizing required emergency action ahead of all other remediation action, in response to the Nsisioken-Ogale dilemma. Beyond UNEP EAR, research suggests that in instances where water was provided, it was inadequate and sporadic, forcing people to drink the contaminated water as they lacked other alternatives. A more recent report also suggests that initial sporadic water supply has ceased altogether [4].

\subsection{Other Public Health Issues}

A very disturbing finding by UNEP [2] is that Ogoni community is unprotected against petroleum pollutants in both outdoor air and drinking water, sometimes occurring at high concentrations. They are also exposed through skin contact to contaminated environmental media, including soil, sediments, and surface water. Also, seeing that the average life expectancy in Nigeria is below 50 years, it may be reasonably fair to assume that most members of the current Ogoniland have lived with protracted oil pollution throughout their lives.

In 10 communities where sampling was carried out, 28 wells were detected to have been contaminated with organic pollutants, seven of whose samples were at least 1000 times higher than the Nigerian drinking water standard of $3 \mu \mathrm{g} / \mathrm{L}$. The sad truth is that despite community awareness of the dangers surrounding use of water from such polluted sources, they lack alternatives.

According to Nriagu [33], many host communities in Niger Delta including Ogoni, continue to suffer diverse range of illnesses arising from exposure to oil pollution, such as blood disorders, cancers of different organs, negative reproductive conditions, impaired disease immunity, and growth; respiratory diseases, and undesirable physiological responses. In fact, in an August 2014 interview with some Ogoni community members, they were reported as having complained of deterioration of health, including bad vision, headache, nose pain and bleeding, asthma, skin rashes, cancer, birth defects, ulcers, heart attacks, and lung and throat infections. Additionally, the women suffer miscarriages and untimely menopause $[2,33]$. However, UNEP posits that there is no existing evidence that suggest any association of oil pollution with the latter [6]. 


\subsection{Benzene}

The study findings also report benzene in all air samples at levels ranging from 0.155 to $48.2 \mu \mathrm{g} / \mathrm{m}^{3}$. The report asserts that an estimated 10 per cent of benzene concentrations detected in Ogoniland were above the specification levels of global regulations such as WHO and the United States Environmental Protection Agency (USEPA). This concentration corresponds to a 1 in 10,000-cancer risk. Benzene is a "known carcinogen" based on occupational studies in adults who demonstrated increased incidence of several types of leukemia on exposure [37,68,69]. Furthermore, the WHO International Agency for Research on Cancer (IARC) in 1998, classified benzene as a known (Group 1) human carcinogen, based on sufficient evidence that it is cancer causing to humans [70]. Evidence suggests that it brings about DNA damage (genotoxicity) in experimental animals [68,69]. Benzene is one of 188 hazardous air pollutants (HAPs) listed under section 112(b) of the 1990 Clean Air Act Amendments and regulated from more than 170 industrial source categories [71].

\section{Discussion}

According to Petroleum (Drilling and Production) Regulations, oil companies are obliged to "adopt all practicable precautions including the provision of up-to-date equipment" to prevent pollution, and must take "prompt steps to control and, if possible, end it", if pollution does occur. They must maintain all installations in good repair and condition in order to prevent "the escape or avoidable waste of petroleum" and cause "as little damage as possible to the surface of the relevant area and to the trees, crops, buildings, structures and other properties thereon. Oil companies are also required to comply with all local planning laws; they may not enter on any area held to be sacred or destroy any thing that is an object of veneration; and they must allow local inhabitants to have access, at their own risk, to roads constructed in their operating areas. Specific rules relating to compensation in the event of infringement of these ..." (cited in Manby) [11].

A crucial finding included in UNEP's report is the fact that SPDC failed in conforming to its own Standard Operating Procedures (SOP), as per Industry Best Practices (IBP), as well as those of the government. This failure is observed in the ramifications of EM, environmental health, as well as policy and regulations. Also, many research studies $[2,60,62,65]$ have consistently pointed to the inadequate implementation of existing environmental protection laws such as the EIA Act, as the principal cause of the Niger Delta environmental degradation. Unless the responsible parties-the Nigerian government and MOC's including SPDC - take adequate action, environmental and public health, as well as policy and socioeconomic problems, which have consistently plagued the region may remain unabated. Based on the issues highlighted in the preceding chapters, possible solutions are discussed in the ensuing paragraphs.

\subsection{Environmental Management/Environmental Management System Model (EM/EMS) Model}

The EIA Act (Decree No. 86 of 1992) requires an EIA to be carried out "where the extent, nature or location of a proposed project or activity is such that it is likely to significantly affect the environment." The public and private sector are enjoined to give "prior consideration" to the environmental effects of any activity before it is embarked upon. An EIA is compulsory in certain cases including oil and gas field development and construction of oil refineries, some pipelines, and processing and storage facilities. The carrying out of EIAs is policed by the Federal Environmental Protection Agency, and by state environmental protection agencies' (cited in Manby [13]). Barrow states that “... Environmental management transcends achieving sustainable development, one of its primary goals, but in addition, it promotes awareness, recognition and informed decision to mitigate hazards to communities, the environment, including plant and animal life, as well as recovery of damaged ecosystems. It also expedites human adaptability enhancement..." ([72], p. 13). Other definitions have been put forth by various scholars and international bodies, including Thompson [73], who suggests that EM is the system that visualizes and in advance prepares for, and circumvents, or provides 
solutions to environmental and resource sustentation problems. Although these translations may indicate diverse approaches, they all have a single theme - environmental preservation, which many have deemed lacking in the agenda of the MOCs operating in the Niger Delta region.

Even though sustainability and sustainable development constitute major EM goals, an overarching goal of EM is environmental public health security (Figure 2). Achieving sustainability and sustainable development fructifies the overarching goal of EM. At this point, it is important to not confuse sustainability and sustainable development. While the former refers to the continuous, uninterrupted ecosystem activity or resource use, signifying steady demands; the latter refers to improvement of human welfare and lifestyles, and in the predictable future, entails growing demands [72]. The Brundtland Commission defines EM as the development that satisfies the needs of the present generation without jeopardizing the ability of future generations to meet their own needs. Both are interrelated and are very important components of EM [72].
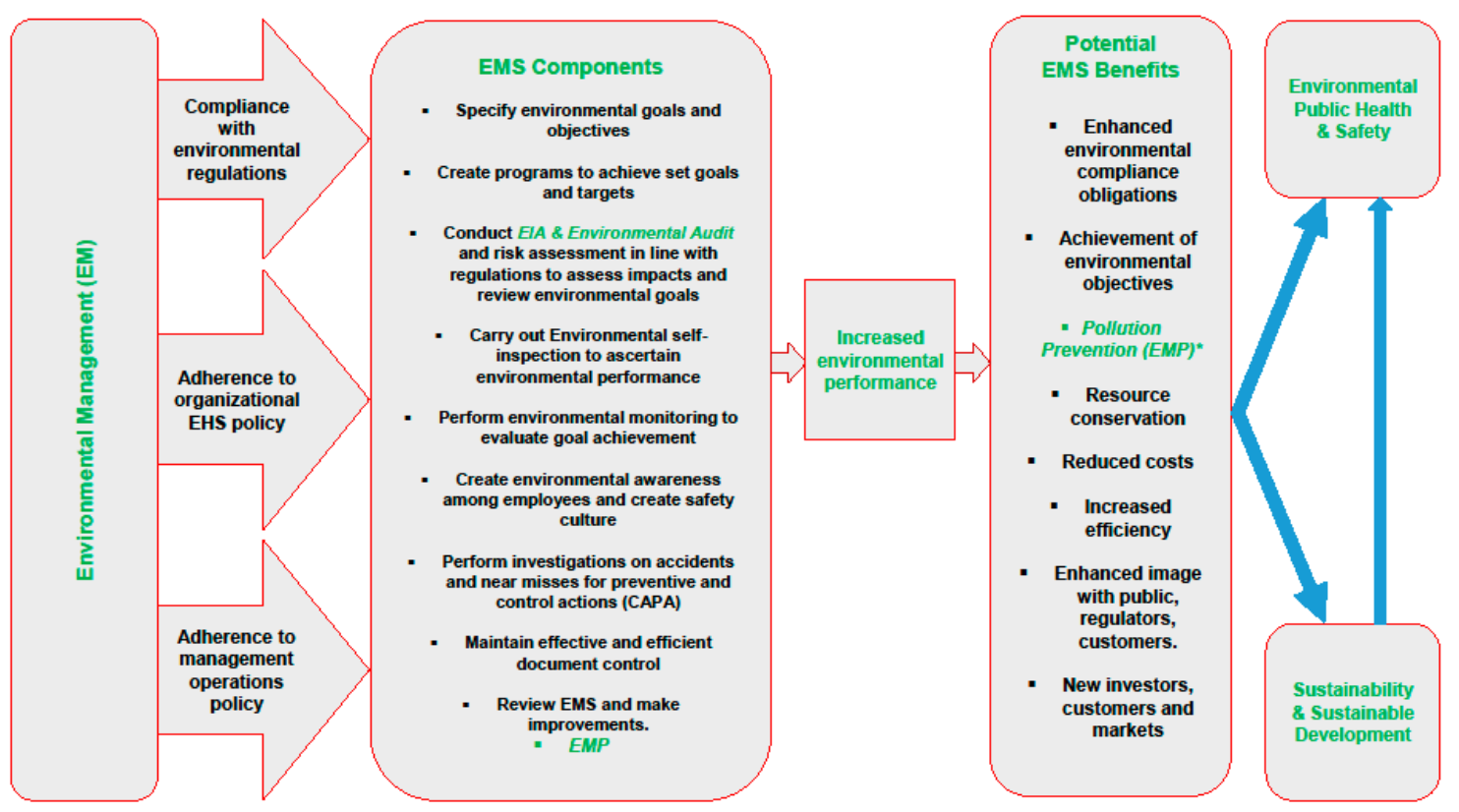

Figure 2. EM/EMS Model. EM-environmental management; EMS—environmental management system; EIA—environmental impact assessment; * EMP—environmental management plan; EHS—environmental health and safety.

According to the USEPA, EMS refers to the structure that affords an organization the potential for attaining its environmental goals, by making adequate provisions for the continual "management affairs" including evaluation, review, and improvement of its environmental performance in a planned and systematic way (Figures 2 and 3). EMS due to its proactive nature, facilitates an organization's capacity to address its regulatory requirements, in not only an organized style, but also in a cost-effective manner, enhancing reduction in non-compliance risk and improvement of public health and safety. Another very important component of EMS is EIA (Figure 2). It is the process of systematically recognizing and appraising the probable effects of proposed prospective legislative actions, plans, programs, or projects, relative to the biological, chemical, cultural, physical, and socioeconomic elements of the environment [74]. On the other hand, environmental audit, simply put, refers to the organized evaluation of the interplay between a business operation and its surrounding environment. This encompasses all effluent discharges to air, land and water legal constraints; ecology, impacts on host community, as well as the public's perception of the business operation in the local area [75]. 


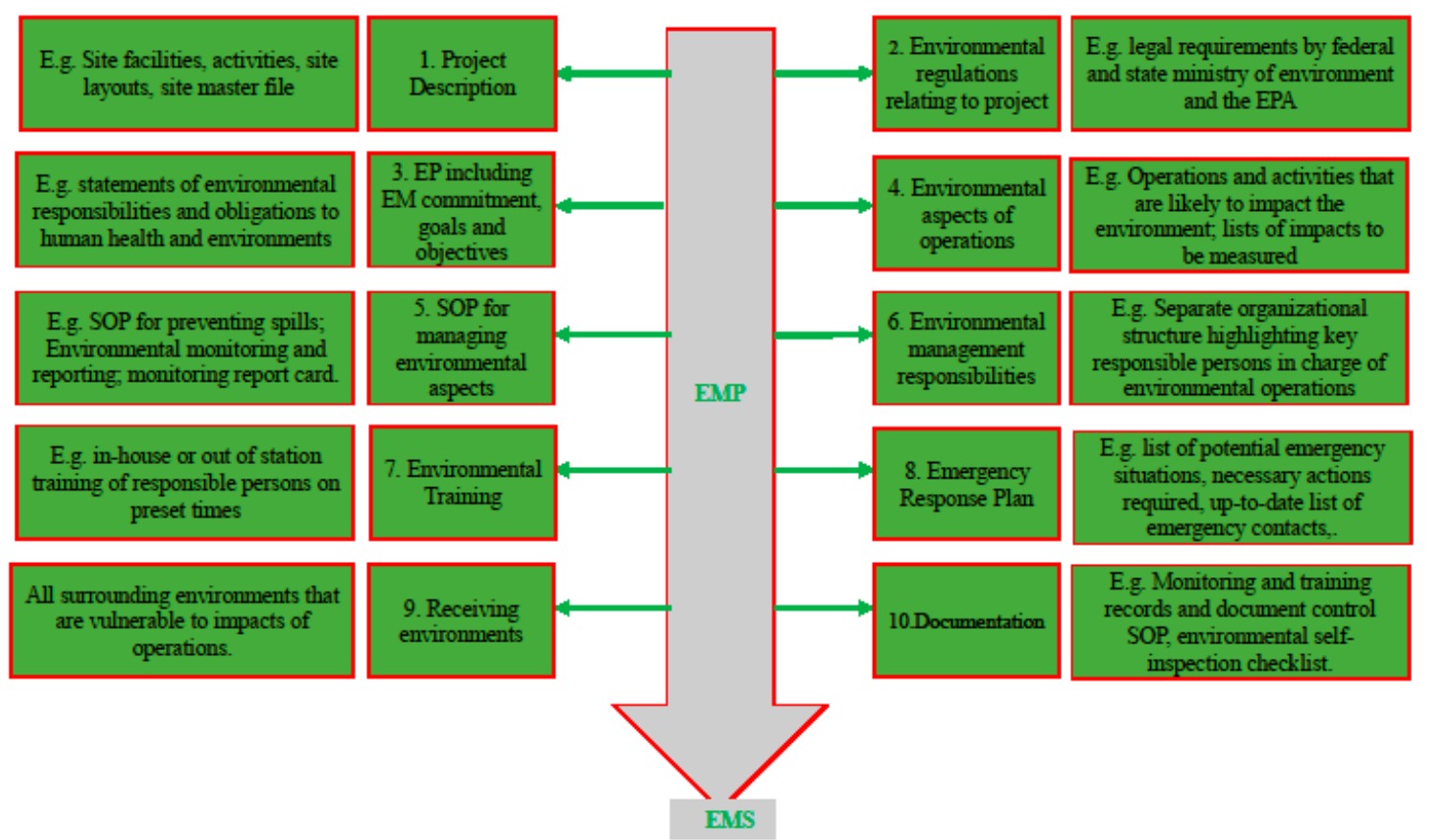

Figure 3. EMP components. $\mathrm{EP}=$ environmental policy; $\mathrm{SOP}$-standard operating procedure; EMS—environmental management systems; EPA—environmental protection agency.

\subsection{Environmental Management Plan (EMP)}

Rizzolo [76] describes EMP (Figure 3) as the plan drawn up during the EIA process that spells out a description of the methods and procedures for checking and reducing impacts. It enhances the awareness and adoption of EM best practices by business and project owners. EMP should be fundamentally entrenched in considerations of resource prevention and pollution abatement, including air pollution, liquid effluents, solid wastes, noise pollution, disaster planning, environmental responsibilities, house-keeping, human settlements, recovery/reuse of waste products, occupational safety and health prevention, maintenance and operation of environment control systems, vegetal cover, among others [77].

The forgoing predicaments are issues that EM seeks to effectively address. In fact, businesses with EM best practices in place may be considered as adopting the "costs of avoidance".

\subsection{Pollution Prevention}

The extent to which EMS is adopted determines what the outcome for pollution prevention is. According to the US Pollution Prevention Act of 1990 [78], pollution prevention also referred to as source reduction, describes the practice of reducing to the barest minimum, the amount of hazardous substances or contaminants introduced into any waste stream, or otherwise discharged into multimedia (air, water and land), prior to recycling, treatment or disposal (Figure 3). It also refers to reduction of hazards to environment and public health, by operations involving the discharge of such contaminants or pollutants.

ISO 14001, the International Organization for Standardization on Environmental Management Systems, defines pollution prevention as the adoption of processes, practices, techniques, materials, products, services, substances or energy that avoid or minimize or control (separately or in combination) the creation, emission or discharge of any type of pollutants or wastes thus reducing adverse environmental impacts [79]. Pollution prevention can be achieved by process or procedure modification, equipment and technology redesign as well as reformulation of products. Improvements in maintenance, housekeeping, inventory control and training programs are all pollution prevention efforts. The benefits of pollution prevention cannot be over emphasized. Businesses enjoy substantial 
benefits from pollution prevention programs including costs savings from reduced raw material, pollution control, and liability costs, as well as environmental preservation, and risks reduction among workers in terms health and safety [80]. In its own view, the European Commission [81] emphasizes the relevance of integrated pollution prevention and control from the perspective of assuring environmental quality by discouraging different approaches that may ultimately bring about shifting of pollution between the different environmental media, and rather adopting holistic measures to safeguard the environment as a whole. This makes up a very important aspect in the efforts to engender a more sustainable balance between human activities and socio-economic development, on the one hand, and resources and the capacity of the earth to adequately regenerate on the other [81]. In contrast, pollution control refers to waste handling or management of wastes generated from industrial processes and operations [80,82]. This end-of-pipe approach has over the years paid off in terms of providing short-term improvements for local pollution problems. However, emphasis have over time shifted to pollution prevention largely owing to risks of transferring pollution from one media to another $[82,83]$ involved in pollution control measures. Furthermore, businesses adopting pollution control measures are burdened with ever increasing costs of abatement processes and operations, and its less effectiveness in addressing cumulative problems on regional (e.g., acid rain) or global (e.g., ozone depletion) levels [83]. It is crucial that pollution prevention be prioritized while pollution control be considered a last resort in EM.

\section{Conclusions}

While my proposed EM/EMS model cannot resolve such issues as government, MOC and regulatory agency commitment to environmental preservation, it will proactively avert environmental degradation by preventing pollution once appropriate measures are taken by the responsible parties to do what is needed. The government must empower existing regulatory bodies and ensure that they adopt established environmental laws in overseeing the MOCs. It is important that existing laws requiring updates should be reviewed and validated to address the prevailing issues. Shell must undergo organizational change in terms of obligations to the environment for EM/EMS model to be viable. With an EMS in place, emphasis is on pollution prevention, thus control measures including its accompanying obligations such as compensation could be reduced to a barest minimum. While compensation is undertaken to effectively remedy pollution and affected community members who suffer from the ravaging consequences of oil pollution, it is not the best option. What is best in my own opinion is "do not pollute in the first place" which is what EM/EMS seeks to achieve. No amount of money can buy back a lost life. In the same vein, there is no open market value for such situations as psychological impairment and terminal diseases such as cancer. Damaged environments may take donkey years to fully recover, involving huge amounts of financial expenses that could have been productively invested elsewhere. Restoration of Ogoniland based on the UNEP EAR is a good example. It becomes almost impossible or increasingly challenging to implement remediation when a system built into the company's operations to forestall pollution is lacking. There is no gainsaying the fact that the environmental damage has a complex and multifaceted offshoot of severe issues which require a multipartite endeavor to effectively address.

Acknowledgments: I would like to thank Blair Stringam of the Department of Plant and Environmental Sciences, and Joseph Gladstone of the Department of Public Health Sciences, New Mexico State University, for kindly reviewing my draft manuscript.

Conflicts of Interest: The authors declare no conflict of interest.

\section{References}

1. Fentiman, A.; Zabbey, N. Environmental Degradation and Cultural Erosion in Ogoniland: A Case Study of the Oil Spills in Bodo. Extr. Ind. Soc. Int. J. 2015, 2, 615-624. [CrossRef]

2. United Nations Environment Program (UNEP). Environmental Assessment of Ogoniland. Available online: http:/ / postconflict.unep.ch/publications/OEA/UNEP_OEA.pdf (accessed on 29 December 2016). 
3. Environmental Rights Action/Friends of the Earth Nigeria; Center for the Environment, Human Rights and Development; Friends of the Earth Europe. Amnesty International No Progress: An Evaluation of the Implementation of UNEP's Environmental Assessment of Ogoniland, Three Years On. 2015. Available online: https:/ / www.amnesty.org.uk/files/unep_briefing_2014_niger_delta.pdf (accessed on 25 February 2017).

4. Platform. Polluted Promises: How Shell Failed to Clean Up Ogoniland. Available online: http:/ / platformlondon.org/wp-content/uploads/2014/05/Polluted_Promises_FINAL_low_res.pdf (accessed on 24 December 2016).

5. BBC News. Nigerians Living in Poverty Rise to Nearly 61\%. Available online: http://www.bbc.com/news/ world-africa-17015873 (accessed on 6 March 2017).

6. Frynas, J.G. Oil in Nigeria: Conflict and Litigation between Oil Companies and Village Communities; LIT Verlag: Hamburg, Germany, 2000.

7. Unrepresented Nations and Peoples Organizations. Available online: http://unpo.org/section/2 (accessed on 29 February 2017).

8. Agbonifo, J. Territorializing Niger Delta Conflicts: Place and Contentious Mobilization. Interface J. Soc. Mov. 2011, 3, 240-265.

9. Saro-wiwa, K. Complete Statement by Ken Saro-Wiwa to Ogoni Civil Disturbances Tribunal. 1995. Available online: https:/ /ratical.org/corporations/KSWstmt.pdf (accessed on 1 March 2017).

10. Frynas, J.G. Corporate and State Responses to Anti-Oil Protests in the Niger Delta. Afr. Aff. 2001, 100, $27-54$. [CrossRef]

11. Manby, B. The Price of Oil: Corporate Responsibility and Human Rights Violations in Nigeria's Oil Producing Communities; Human Rights Watch: New York, NY, USA, 1999; pp. 1-193.

12. Pegg, S. Introduction: On the 20th Anniversary of the Death of Ken Saro-Wiwa. Extr. Ind. Soc. Int. J. 2015, 2, 607-614.

13. Tamuno, S.; Felix, J.M. Crude Oil Resource: A Blessing or Curse to Nigeria-The Case of the Niger Delta. J. Res. Natl. Dev. 2006, 4, 53-58. [CrossRef]

14. African Vault. Top 20 Oil Producing Countries in Africa. Available online: http://www.africanvault.com/ oil-producing-countries-in-africa/ (accessed on 13 December 2016).

15. Pitkin, J. Oil, Oil, Everywhere: Environmental and Human Impacts of Oil Extraction in the Niger Delta. Bachelor Thesis, Pomona College, Claremont, CA, USA, 2013.

16. Balouga, J. The Niger Delta: Defusing the Time Bomb. International Association for Energy Economics, 2009. Available online: https://www.iaee.org/documents/newsletterarticles/109balouga.pdf (accessed on 27 December 2016).

17. Barbier, E.B.; Acreman, M.C.; Knowler, D. Economic Valuation of Wetlands, a Guide for Policy Makers and Planners; Ramsar Convention Bureau: Gland, Switzerland, 1997.

18. Wetlands International. Conserving and restoring wetlands in Nigeria's Niger River Delta. Available online: https: / /www.wetlands.org/casestudy/conserving-and-restoring-wetlands-in-nigeriasniger-river-delta/ (accessed on 28 December 2016).

19. Ite, A.E.; Ibok, U.J. Gas Flaring and Venting Associated with Petroleum Exploration and Production in the Nigeria's Niger Delta. Am. J. Environ. Prot. 2013, 1, 70-77. [CrossRef]

20. Okonkwo, C.N.P.; Kumar, L.; Taylor, S. The Niger Delta Wetland Ecosystem: What Threatens It and Why Should We Protect It? Afr. J. Environ. Sci. Technol. 2015, 9, 451-463.

21. Ogri, O.R. A review of the Nigerian petroleum industry and the associated environmental problems. Environmentalist 2001, 21, 11-21. [CrossRef]

22. Godson, A.R.; Sridhar, M.K.; Bamgboye, E.A. Environmental Risk Factors and Health Outcomes in Selected Communities of the Niger Delta Area, Nigeria. Perspect. Public Health 2009, 129, 183-191.

23. Ndubuisi, O.L.; Asia, I.O. Environmental Pollution in Oil Producing Areas of the Niger Delta Basin, Nigeria: Empirical Assessment of Trends and People's Perception. Environ. Res. J. 2007, 1, 18-26.

24. Bestoyin, K.O. Democracy and Development: A Comparative Analysis of Nigeria and Malaysia. Am. J. Humanit. Soc. Sci. 2015, 3, 70-82.

25. Tijen, D.; Scott, P. Razed, Repressed and Bought Off: The Demobilization of the Ogoni Protest Campaign in the Niger Delta. Extr. Ind. Soc. 2015, 2, 654-663.

26. Senewo, I. The Ogoni Bill of Rights: Extent of actualization 25 years later? Extr. Ind. Soc. 2015, 2, 664-670. [CrossRef] 
27. Europe-Third World Centre (CETIM); Environmental Rights Action/Friends of the Earth Nigeria (ERA/FoEN). Cases of Environmental Human Rights Violations by Shell in Nigeria's Niger Delta. Available online: http:/ / www.cetim.ch/wp-content/uploads/G1404473.pdf (accessed on 26 December 2016).

28. Barry, F.B. Environmental Injustices: Conflict and Health Hazards in the Niger Delta. Master's Thesis, American University, Washington, NW, USA, 2010.

29. Buzcu-Guven, B.; Harriss, R. Extent, Impacts and Remedies of Global Gas Flaring and Venting. Carbon Manag. 2012, 3, 95-108. [CrossRef]

30. Emam, E.A. Environmental Pollution and Measurement of Gas Flaring. Int. J. Innov. Res. Sci. Eng. Technol. 2016, 2, 252-262.

31. Agbola, T.; Olurin, T. Landuse and Landcover. Change in the Niger Delta; Excerpts from a Research Report; Centre for Democracy and Development: Abuja, Nigeria, 2003.

32. Fridtjof Nansen Institute. Gas Flaring and Global Public Goods. Available online: https://www.fni.no/ getfile.php/132146/Filer/Publikasjoner/FNI-R2001.pdf (accessed on 1 March 2017).

33. Nriagu, J. Oil Industry and the Health of Communities in the Niger Delta of Nigeria. In Encyclopedia of Environmental Health; Jerome, O.N., Ed.; Elsevier: Burlington, NJ, USA, 2011; pp. 240-250.

34. Kostiuk, L.; Johnson, M.; Thomas, G. University of Alberta Flare Research Project; Final Report November 1996-September 2004; University of Alberta, Department of Mechanical Engineering: Edmonton, AB, Canada, 2004.

35. Uyigue, E.; Agho, M. Coping with Climate Change and Environmental Degradation in the Niger Delta of Southern Nigeria. Community Research and Development, Centre Benin City. Available online: http:/ / priceofoil.org/content/uploads/2007/06/07.06.11\%20-\%20Climate_Niger_Delta.pdf (accessed on 26 February 2017).

36. Ibitoye, F.I. Ending Natural Gas Flaring in Nigeria's Oil Fields. J. Sustain. Dev. 2014, 7, 9063-9071. [CrossRef]

37. Agency for Toxic Substances and Disease Registry (ASTDR). Toxicological Profile for Benzene. Available online: https:/ /www.atsdr.cdc.gov/toxprofiles/tp3-p.pdf (accessed on 24 December 2016).

38. Environmental Rights Action/Friends of the Earth (ERA/FoE). Gas Flaring in Nigeria: A Human Rights, Environmental and Economic Monstrosity. Available online: https://www.foe.co.uk/sites/default/files/ downloads/gas_flaring_nigeria.pdf (accessed on 27 December 2016).

39. Agency for Toxic Substances and Diseases Registry (ASTDR). Nitrogen Oxides. Available online: https:/ / www.atsdr.cdc.gov/toxfaqs/tfacts175.pdf (accessed on 22 December 2016).

40. Agency for Toxic Substances and Diseases Registry (ASTDR). Interaction Profile for Benzene, Toluene, Ethylbenzene and Xylene. Available online: https:/ / www.atsdr.cdc.gov/interactionprofiles/ip-btex/ip05-c3.p (accessed on 18 December 2016).

41. Gobo, A.; Richard, G.; Ubong, I. Health Impact of Gas Flares on Igwuruta/Umuechem Communities in Rivers State. J. Appl. Sci. Environ. Manag. 2010, 13, 27-33. [CrossRef]

42. Sheppard, D.; Wong, W.S.; Uehara, C.F.; Nadel, J.A.; Boushey, H.A. Lower Threshold and Greater Bronchomotor Responsiveness of Asthmatic Subjects to Sulfur Dioxide. Am. Rev. Respir. Dis. 1980, 122, 873-878. [PubMed]

43. Bethel, R.A.; Erle, D.J.; Epstein, J.; Sheppard, D.; Nadel, J.A.; Boushey, H.A. Effect of Exercise Rate and Route of Inhalation on Sulfur-Dioxide-Induced Bronchoconstriction in Asthmatic Subjects. Am. Rev. Respir. Dis. 1983, 128, 592-596. [PubMed]

44. Kirkpatrick, M.B.; Sheppard, D.; Nadel, J.A.; Boushey, H.A. Effect of the Oronasal Breathing Route on Sulfur Dioxide-Induced Bronchoconstriction in Exercising Asthmatic Subjects. Am. Rev. Respir. Dis. 1982, 125, 627-631. [PubMed]

45. Nwaoguikpe, R.N. The Effect of Crude Oil Spill on the Ascorbic Acid Content of Some Selected Vegetable Species: Spinach Oleraceae, Solanum Melongena and Talinum Triangulare in an Oil Polluted Soil. Pak. J. Nutr. 2011, 10, 274-281.

46. Osam, M.U.; Wegwu, M.O.; Uwakwe, A.A. The Omoku Old Pipeline Oil Spill: Total Hydrocarbon Content of Affected Soils and the Impact on the Nutritive Value of Food Crops. Arch. Appl. Sci. Res. 2011, 3, 514-521.

47. Ordinioha, B.; Brisbe, S. The Human Health Implications of Crude Oil Spills in the Niger Delta, Nigeria: An Interpretation of Published Studies. Niger. Med. J. 2013, 54, 10-16. [CrossRef] [PubMed]

48. Clinton, H.I.; Ujagwung, G.U.; Horsfall, M. Evaluation of Total Hydrocarbon Levels in Some Aquatic Media in an Oil Polluted Mangrove Wetland in the Niger Delta. Appl. Ecol. Environ. Res. 2009, 7, 111-120. [CrossRef] 
49. Andrade, V.T.; Andrade, B.G.; Costa, B.R.S.; Pereira, O.A., Jr.; Dezotti, M. Toxicity Assessment of Oil Field Produced Water Treated by Evaporative Processes to Produce Water to Irrigation. Water Sci. Technol. 2010, 62, 693-700. [CrossRef] [PubMed]

50. Kharaka, Y.K.; Otton, J.K. Environmental Impacts of Petroleum Production: Initial Results from the Osage-Skiatook Petroleum Environmental Research Sites, Osage County, Oklahoma. Water-Resources Investigations Report 03-4260. Available online: https://pubs.usgs.gov/wri/wri03--4260/ (accessed on 25 December 2016).

51. Telleza, G.T.; Nirmalakhandan, N.; Gardea-Torresdey, J.L. Performance Evaluation of an Activated Sludge System for Removing Petroleum Hydrocarbons from Oilfield Produced Water. Adv. Environ. Res. 2002, 6, 455-470. [CrossRef]

52. Agbebi, F.O. Impact of Fish Farming on Poverty Alleviation in Ekiti State. Int. J. Sci. Nat. 2011, 2, 456-460.

53. Ejelonu, B.C.; Adeleke, B.B.; Ololade, I.O.; Adegbuyi, O. The Chemistry of Rainwater Samples Collected Within Utorogu-Oil Producing Community in Niger Delta, Nigeria II. Eur. J. Sci. Res. 2011, 58, 189-203.

54. Nduka, J.K.; Orisakwe, O.E. Water-Quality Issues in the Niger Delta of Nigeria: A Look at Heavy Metal Levels and Some Physicochemical Properties. Environ. Sci. Pollut. Res. 2010, 18, 237-246. [CrossRef] [PubMed]

55. Efe, S.I. Spatial Variation in Acid and Some Heavy Metal Composition of Rainwater Harvesting in the Oil-Producing Region of Nigeria. Nat. Hazards 2010, 55, 307-319. [CrossRef]

56. Nwankwo, C.; Ogagarue, D. Effects of Gas Flaring On Surface and Ground Waters in Delta State Nigeria. J. Geol. Min. Res. 2011, 3, 131-136.

57. Boele, R.; Fabig, H.; Wheeler, D. Shell, Nigeria and the Ogoni. A Study in Unsustainable Development: The Story of Shell, Nigeria and the Ogoni People-Environment, Economy, Relationships: Conflict and Prospects for Resolution. Sustain. Dev. 2001, 9, 74-86. [CrossRef]

58. Zabbey, N.; Hart, A. Preliminary Checklist of Macrozoobenthos of Bodo Creek in the Niger Delta, Nigeria. Niger. J. Fish. 2011, 8, 271-283.

59. Zabbey, N.; Hanson, U. Community Responses of Intertidal Soft-Bottom Macrozoobenthos to Oil Pollution in a Tropical Mangrove Ecosystem, Niger Delta, Nigeria. Mar. Pollut. Bull. 2014, 82, 167-174. [CrossRef] [PubMed]

60. Zabbey, N.; Hart, A.I. Spatial Variability of Macrozoobenthic Diversity on Tidal Flats of the Niger Delta, Nigeria: The Role of Substratum. Afr. J. Aquat. Sci. 2014, 39, 67-76. [CrossRef]

61. Zabbey, N.; Malaquias, M.A. Epifauna Diversity and Ecology on Intertidal Flats in the Tropical Niger Delta, With Remarks on the Gastropod Species Haminoea Orbignyana. J. Mar. Biol. Assoc. 2013, 93, 249-257. [CrossRef]

62. Ite, A.E.; Ibok, U.J.; Ite, M.U.; Petters, S.W. Petroleum Exploration and Production: Past and Present Environmental Issues in The Nigeria's Niger Delta. Am. J. Environ. Prot. 2013, 4, 78-90. [CrossRef]

63. Odisu, A.T. The Nigerian State, Oil Multinationals and the Environment: A Case Study of Shell Petroleum Development Company (SPDC). J. Public Adm. Policy Res. 2015, 7, 24-28. [CrossRef]

64. Allen, F. The Enemy Within: Oil in the Niger Delta. World Policy Institute. Available online: http:/ / www.worldpolicy.org/ (accessed on 26 November 2016).

65. Amnesty International. Nigeria: Petroleum, Pollution and Poverty in the Niger Delta. Available online: https:/ / www.amnesty.de/files / Amnesty_Bericht_Niger_Delta_09.pdf (accessed on 26 December 2016).

66. Department of Petroleum Resources (DPR). Environmental Guidelines and Standards for Petroleum Industry in Nigeria (EGASPIN); DPR: Lagos, Nigeria, 2002.

67. Ofuani, O.I. Environmental Regulation of Offshore (E\&P) Waste Management in Nigeria: How Effective? Law Environ. Dev. J. 2011, 7, 79-99.

68. U.S. Environmental Protection Agency (USEPA). Carcinogenic Effects of Benzene: An Update. Available online: https: / / cfpub.epa.gov/ncea/risk/recordisplay.cfm?deid=2806 (accessed on 24 December 2016).

69. U.S. Environmental Protection Agency (USEPA). Toxicological Review of Benzene (Non-cancer Effects). Available online: https://cfpub.epa.gov/ncea/iris/iris_documents/documents/toxreviews/0276tr.pdf (accessed on 28 December 2016).

70. International Agency for Research on Cancer (IARC). IARC Monographs on the Evaluation of the Carcinogenic Risk of Chemicals to Humans: Some Industrial Chemicals and Dyestuffs; IARC: Lyon, France, 1982; Volume 29, pp. 94-148. 
71. U.S. Environmental Protection Agency (USEPA). Technology Transfer Network Air Toxics Assessment: Original List of Hazardous Air Pollutants. Available online: http://www.epa.gov/ttn/atw/188polls.html (accessed on 24 December 2016).

72. Barrow, C.J. Environmental Management and Development, 2nd ed.; Routledge: New York, NY, USA, $2004 ;$ p. 13.

73. Thompson, D. Tools for Environmental Management: A Practical Introduction and Guide; New Society Publishers: Gabriola Island, BC, Canada, 2002.

74. Council on Environmental Quality (CEQ). The Twenty-fourth Annual Report of the Council on Environmental Quality (U.S.). Available online: https://ceq.doe.gov/nepa/reports/1993/toc.htm (accessed on 28 December 2016).

75. Confederation of British Industry (CBI). Narrowing the Gap: Environmental Auditing Guidelines for Businesses; CBI: London, UK, 1990.

76. Rizzolo, J. Environmental Management: Code of Practice for the Building and Construction Industry. Ballymun Regeneration Ltd.-Health \& Safety Management Unit. Available online: http://www.brl.ie/pdf/ ENVIRONMENTAL\%20MANAGEMENT.pdf (accessed on 26 December 2016).

77. Ministry of Environment, Forest and Climate Change (India). Environmental Management Plan (EMP). Available online: http:/ / www.moef.gov.in/citizen/specinfo/emp.html (accessed on 24 December 2016).

78. U.S. Environmental Protection Agency (USEPA). Pollution Prevention Act of 1990. Available online: https:/ / www.epa.gov/p2/pollution-prevention-act-1990 (accessed on 25 December 2016).

79. International Organization for Standardization (ISO). ISO 14001:2015-Environmental Management Systems_Requirements with Guidance for Use, 3rd ed.; ISO: Geneva, Switzerland, 2015.

80. U.S. Environmental Protection Agency (USEPA). Learn About Environmental Management Systems. 2016. Available online: https://www.epa.gov/ems/learn-about-environmental-management-systems (accessed on 28 December 2016).

81. European Commission. Council Directive 96/61/EC of 24 September 1996 Concerning Integrated Pollution Prevention and Control. Available online: http://socios.ainia.es/mambiente/Doc/directiva\%20ingles.pdf (accessed on 27 December 2016).

82. Owa, F.D. Water Pollution: Sources, Effects, Control and Management. Mediterr. J. Soc. Sci. 2013, 4, 65-68. [CrossRef]

83. Spiegel, J.; Maystre, L.Y. Environmental pollution control. In Encyclopedia of Occupational Health and Safety, 4th ed.; Stellman, J.M., Ed.; International Labor Office: Geneva, Switzerland, 1998; Volume 4. 